\title{
Quando a língua carrega estigmas: ideologias linguísticas Paumari e Apurinã no município de Lábrea
}

\author{
When the language carries stigmas: linguistic ideologies Paumari and Apurina in the \\ county of Lábrea \\ Ana Carla dos Santos BRUNO* \\ Instituto Nacional de Pesquisas da Amazônia (INPA)
}

\begin{abstract}
RESUMO: Neste artigo analisamos as experiências de jovens indígenas e suas famílias no contexto urbano no município de Lábrea. Nós discutimos as ideias, crenças, representações e atitudes que os Apurinã e Paumari tem sobre suas línguas e a língua Portuguesa utilizando a abordagem da Ideologia Linguística. Através do método etnográfico observarmos assim, as situações rotineiras de interação nas diferentes esferas das atividades sociais: em casa, na escola, com "os outros" e com seus parentes para uma melhor compreensão das representações que os mesmos têm sobre a vida na cidade e suas experiências nas escolas urbanas.
\end{abstract}

PALAVRAS-CHAVE: Ideologias linguísticas. Línguas indígenas. Paumari. Apurinã.

ABSTRACT: In this article we analyze the experience of young indigenous students and their families in the urban context of Lábrea municipality. We discuss the ideas, beliefs, representations, and attitudes that the Apurinã and Paumari peoples have about their languages and the Portuguese language utilizing the Language Ideology approach. Through an ethnographic method, we observe the routine situations of interaction in the different spheres of social activities: at home, at school, with the "others" and with their relatives for a better understanding of the representations that they have about life in the city and their experiences in urban schools.

KEYWORDS: Linguistc ideologies. Indigenous language. Paumari. Apurinã.

\section{Introdução}

Neste artigo, elaboramos uma primeira reflexão sobre as ideologias linguísticas e situações vivenciadas por alguns jovens indígenas (e seus familiares) no contexto escolar, no universo urbano do município de Lábrea. Buscando-se assim compreender os sistemas de disposições sociais dos Paumari e Apurinã em seu manejo da língua

\footnotetext{
* Doutora em Antropologia Linguística pela Universidade do Arizona. Pesquisadora titular III do Instituto Nacional de Pesquisas da Amazônia, da Coordenação de Sociedade Ambiente e Saúde (INPA/COSAS). <abruno@inpa.gov.br>
} 
indígena como parte de um domínio particular e distintivo do corpo (BOURDIEU, 2008, p. 13). Neste sentido, através do método etnográfico, observarmos as situações rotineiras de interação nas diferentes esferas das atividades sociais: em casa, na escola, com "os outros" e com seus parentes para uma melhor compreensão da produção deste "Mercado Linguístico" e das representações que os mesmos têm sobre suas línguas e a língua Portuguesa.

"Logo que chegamos aqui, eu sempre falava para ele (p/ o marido), eu sei que não vai dar certo e que nossos filhos estão nascendo, vão estudar bem aqui, só que não vai adiantar nada este estudo deles aqui, eles vão perder o nosso idioma, eu falava para ele (p/ o marido). Aqui eles vão aprender, vão estudar outras línguas, mas a nossa vai ficar para trás. (Indígena Paumari)

\footnotetext{
“...o pai dos meus filhos, ele é branco então para você vê agora eu passo por outros tipos de preconceitos e foi na época que eu me reconheci como indígena vendo minha mãe lutar no movimento. Quando foi para minha filha entrar na escola, você não diz que eles são indígenas porque puxaram tudo para o pai. Então eles não sofreram preconceito por parte dos colegas. Mas eles se identificavam como indígena. A minha filha de 14 anos, uma professora uma vez perguntou para ela porque ela tinha se identificado como indígena se ela falava Português bem. Então ela respondeu:

- Professora, se minha mãe é indígena, eu sou o quê? Eu posso não ter aparência, mas o sangue que corre é sangue de índio." (Indígena Apurinã)
}

A partir dos discursos dos agentes sociais e de suas práticas buscamos examinar a produção de territorialidades linguísticas tentando compreender: Quais posturas e atitudes têm as diferentes gerações e os grupos em relação ao uso da língua? Desta forma, acompanhamos estes sujeitos no seu cotidiano, nos seus afazeres domésticos, nas suas idas para eventos, escola, reuniões. Durante um ano e meio acompanhamos, conversarmos e entrevistamos pais, jovens estudantes indígenas e não indígenas e professores. Entramos em suas casas e percebermos um pouco de suas vidas, o lugar de suas intimidades, expectativas e sonhos. Participamos de reuniões, eventos e frequentamos as aulas e atividades na escola. Cada fala, cada ação, cada posicionamento nesses eventos possibilitavam leituras múltiplas que nos remetiam a diversos contextos (mais situacional, mais local e muitas vezes nacional que reflete a situação não só de Lábrea, mas de diversos municípios cuja presença indígena nas cidades aumentam).

Atentamos, sobretudo, para o uso da língua indígena, suas crenças e percepções sobre as mesmas e como os indígenas eram percebidos pelos não indígenas neste contexto. Para isso, tomamos como base a Etnografia Multisituada (MARCUS, 1995), que se caracteriza por um exercício de mapear um terreno no sistema mundo, onde o 
objeto de estudo possui várias dimensões que devemos seguir, como uma trama. Desta forma, buscamos o método etnográfico 'concebido como a procura incessante de diálogo com os sujeitos envolvidos na pesquisa (PEIRANO, 1995, p.162).

\section{Trajetória da Pesquisa}

Uma das características das cidades da região do Médio Purus é a diversidade sociocultural da população nelas existentes destacando-se sobretudo sua multietnicidade e diversidade linguística. De acordo com Mendes (2011) esta região tem sido vitimizada por um processo e cenário das mais variadas experiências desenvolvimentistas para a Amazônia: impacto do sistema de aviamentos e empresas seringalistas, pecuarização e implementação de monocultivos. Por outro lado, encontramos também nesta região um fenômeno cada vez mais observado nas cidades amazônicas - a presença de indígenas no espaço urbano.

Através de uma oficina realizada em outubro de 2010 pela equipe do Projeto Nova Cartografia Social (coordenada pela Dra. Thereza Menezes - naquele período professora do Programa de Pós-Graduação em Antropologia Social da UFAM) tivemos a possibilidade de aproximar-nos de uma realidade até então desconhecida (o município de Lábrea). Esta oficina nos permitiu observar e conhecer alguns atores sociais que sofrem os efeitos de processos de violências simbólicas (BOURDIEU, 2004; DAS, 1995, 1999, 2007).

Neste primeiro contato com os indígenas, três depoimentos interessou-nos sobremaneira, elucidando nossas reflexões sobre língua e desigualdade social e língua e ideologias linguísticas (KROSKRITY, 2000a; IRVINE; GAL, 2000). Eles revelam, repetimos, uma situação de extrema violência simbólica e o que Bourdieu (2008) chama de uma Hexis Corporal em relação à percepção dos não- indígenas ao que se refere aos indígenas:

\footnotetext{
"Existe bastante preconceito em relação as mulheres indígenas na cidade, pois a gente não anda igual ás mulheres que não são indígenas, né. As mulheres indígenas, elas sempre andam mal vestidas, sem sutiã; $\mathrm{O}$ jeito delas falarem e quando andam, andam com um monte de filho. Na aldeia, a gente anda assim quando a gente vai para um roçado, ou para uma festa, ou para algum lugar, a gente leva todo mundo. Elas (as mulheres não-indígenas) falam que nojo faz essas mulheres que falam na gíria, na língua indígena." (Indigena Paumari)
} 


\begin{abstract}
"Viver na cidade é difícil porque é uma língua diferente, tem que se vestir diferente e se comportar diferente, nós na aldeia fazemos coisas diferentes." (Indígena Paumari)

"O preconceito aqui a gente encontra mais é dentro da sala de aula, por exemplo o que aconteceu com minha filha. Ela estudava na Escola Santo Agostinho. Como ela é indígena, né! As coleguinhas dela quando descobriram que ela é indígena (as características dela também demonstram isso), elas começaram a não brincar mais com ela, não fazer trabalhos de grupo, elas sempre excluíam ela.. E chamavam de "cabocla velha", "cabocla fedorenta"...estas coisas. Uma criança com 12 anos escutava isso, ela sentia vergonha e as vezes chegava em casa chorando." (Indígena Paumari)
\end{abstract}

Segundo Bourdieu (2008, p. 74) é possível observar que existe "um sentido de aceitabilidade que orienta as práticas linguísticas e que está inscrito no registro mais profundo das disposições corporais: é o corpo inteiro que responde à tensão do mercado por sua postura. A linguagem é uma técnica do corpo onde se exprimem toda a relação do mundo social e toda relação instruída com o mundo". A primeira fala mencionada acima expõe e retrata a noção de signos incorporados que envolvem maneira de se vestir, andar, comportar-se e falar que embute e configura todo um processo de poder simbólico, de ideologias linguísticas (GAL, 1998; COLLINS, 1998) e de língua e desigualdade social (PHILIPS, 2006; AGHA, 2007). Bourdieu (2004; 2008) defende que cada troca linguística contém a potencialidade de um ato de poder e não somente um particular sistema de palavras ou de regras gramaticais, mas algo que é sempre escondido por meio de um poder simbólico e de uma forma particular de se comunicar. Por meio do uso da língua, nós criamos diferenciações entre identidades grupais e individuais (HANKS, 2008; PHILIPS, 2006).

Neste sentido, no caso desta pesquisa etnográfica realizada em Lábrea com os Paumari (BONILLA, 2005; 2007; CHAPMAN; SALZER 1998) e Apurinã (FACUNDES, 2000, 2002; SCHIEL, 2000, 2004) observarmos que as línguas indígenas estão saindo do âmbito e limites doméstico/familiar e agora podem ser escutadas (mesmo que às vezes num tom mais baixo e velado, pois foram muitas vezes silenciadas) em espaços públicos como escolas, bancos, postos de saúde e praças.

Os Paumari habitam a bacia do Médio rio Purus e seus afluentes, como os rios Ituxi, Sepatini e Tapauá, ao Sul do Estado do Amazonas, e ocupam duas áreas geograficamente distantes: as áreas do rio Ituxi e lago Marahã, localizados nas proximidades do município de Lábrea e das áreas dos lagos Manissuã, Paricá e Cuniuá, localizados pouco acima da foz do rio Tapauá. Nas aldeias, eles têm como principal atividade a pesca de peixes e quelônios, preparação de pequenos roçados e coleta de 
frutas. De acordo com dados da FUNAI/Purus de 2010, a população constava de aproximadamente 1470 indígenas. São falantes de uma língua que leva o mesmo nome do grupo pertencente à família linguística Arawá e que tem sido estudada pelos missionários do Summer Institute of Linguistics (SIL) desde final dos anos 60 (BONILLA, 2005).

Os Apurinã habitam a região do médio rio Purus, entre os municípios de Pauini, Lábrea e Tapauá. Eles têm suas residências fora das margens dos rios. Pescam, coletam quelônios e preparam roçados que tem como principal produto - a mandioca. (Schiel, 2004) e muitos vivem no universo urbano (VIRTANEN, 2015). De acordo com dados do IBGE de 2010 (informado no site da Fundação Nacional do Índio - FUNAI), a população Apurinã é de aproximadamente 8 mil pessoas. Falam uma língua com o mesmo nome da etnia e que pertence a família linguística Maipure-Arawak, do ramo Purus (FACUNDES, 2000).

Segundo Bonilla (2005, p. 41), no cotidiano, os Paumari usam frequentemente o Português para se comunicar entre si, associando estruturas frasais em Português e vocabulário Paumari. Por outro lado, de acordo com Facundes (2000), Schiel (2004), Brandão (2006) e Nascimento Costa (2015), o número de falantes fluentes de Apurinã na região do Purus (Lábrea, Pauini e Boca do Acre) está vinculado a um número reduzido de agentes sociais da geração de idosos. De acordo com Lima (2013, p. 22), entre os Apurinã observam-se diferentes realidades sociolinguísticas: (a) grupos praticamente monolíngues em Apurinã; (b) grupos bilíngues, cuja língua Apurinã ainda é produtiva; (c) grupos em que o Apurinã é usado somente pelos mais velhos; (d) grupos cuja língua Apurinã foi praticamente substituída pela língua portuguesa, sendo que a maioria ou até todas as pessoas que os constituem não conhecem quase nada de sua língua materna. $\mathrm{Na}$ cidade de Lábrea, os Apurinã que entrevistamos, em sua maioria, são monolíngues em Português.

Tanto os Paumari quanto os Apurinã foram envolvidos na economia do aviamento instigada no Purus no final do século XIX. As duas etnias também foram alvos de massacres, perseguições e matanças vivenciando certamente situações de terror (Taussing 1993) que se refletem nas posturas, representações e produções de silêncio vivenciadas no presente.

"Na escola, meus irmãos estavam estudando e teve um grupo que estudava com eles que só depois de um tempo disseram que eram indígenas. E meus irmãos perguntaram: 


\begin{abstract}
'- Por que vocês não falaram que eram indígenas pra gente?' E eles disseram que não porque tinham vergonha. Tem muitas pessoas que pensam assim mesmo. Ainda falam a língua, moram na aldeia e vem para aula na cidade, mas tem vergonha porque passaram por muita violência, muita vergonha, muita discriminação e quando as pessoas falavam: '- Vixe tá cortando gíria'!' Para eles é uma vergonha mesmo tendo muitos grupos que estão ao redor deles CIMI, OPAN, AMIMP, FOCIMP que valorizam, mas mesmo assim tem gente que tem muita vergonha. (Indígena Apurinã)
\end{abstract}

"Como os Apurinã foram os que mais se debateram contra os brancos, eles não falam sua própria língua na cidade, os poucos que sabem falar na cidade, eles não falam não se comunicam porque sofreram muito preconceito e todo tipo de violência..." (Indígena Apurinã).

“...por desconhecerem seus direitos e não falar bem o Português, eles se intimidam e são tratadas com descaso nos serviços públicos, principalmente nos serviços de Saúde, hospital da cidade. (Indígena Apurinã)

"Do preconceito de ser indígena, então eu vim descobri que era indígena e assumi a identidade em 99. Minha mãe estava no movimento indígena e eu não aceitava bem não...como no meu olhar, eu não me achava indígena e quando as pessoas falavam de indígena era totalmente diferente do que eu pensava. Eu não falo a língua, meu avô falava, mas não aceitava ser indígena devido tanta violência que ele viu entre indígenas e branco. Então ele se afastou né. A mãe dele deu ele para outra pessoa, então ele foi criado em cultura diferente. Nós fomos criado nisso né.” (Indígena Apurinã)

\title{
2. Vida na Cidade
}

A migração indígena para centros urbanos intensificou-se bastante nas últimas décadas na região amazônica. A grande precariedade das condições de atendimento a saúde e educação nas áreas indígenas e a expectativa de encontrar na cidade trabalho, continuidade dos estudos e uma vida melhor costuma justificar a migração. Os indígenas que vivem em áreas urbanas somam 324 mil, ou seja, 36\% do total da população indígena, um número que vem crescendo ano após ano (IBGE, 2010). É preciso atentar também que em alguns municípios, as cidades cada vez mais aproximam-se das Terras Indígenas.

A escola representa um forte fator de atração para algumas famílias indígenas deslocarem-se para as cidades. No entanto, existe um complexo e diverso conjunto de motivos que levam indivíduos ou famílias inteiras deixarem suas aldeias. Os deslocamentos para a cidade também ocorrem pela busca de diversos serviços públicos, benefícios sociais e informações referentes ao INSS, bancos, prefeituras, as

\footnotetext{
${ }^{1}$ Noção estigmatizada, expressão utilizada preconceitosamente para as línguas indígenas.
} 
secretarias de educação e saúde, FUNAI e organizações não governamentais que apoiam a questão indígena. É importante ressaltar que em muitas situações estas motivações são experienciadas de forma simultânea, confundem-se e complementam-se de forma complexa. (MENEZES ; BRUNO, 2014, p. 5)

\subsection{Bairro da Fonte - Efeitos do Lugar}

"Ninguém quer ir morar no Bairro da Fonte porque é bairro de índio." (Indigena Apurinã).

É possível notarmos condições sociais e materiais desiguais que produzem centros e periferias formando fronteiras que se reconstituem e se renovam gerando grupos sociais que são excluídos e colocados à margem. (BHABHA, 2011). Em Lábrea, essa situação reflete-se num bairro que é colocado em todos seus aspectos como um universo periférico tanto do ponto de vista geográfico quanto econômico, social e étnico. Nele residem os caboclos, os indígenas, os misturados, os que não têm tanta condição social e econômica, como repetidas vezes foram mencionadas nas entrevistas realizadas. Apesar do bairro da Fonte estar localizado na zona urbana de Lábrea, ele situa-se nas fronteiras de uma Terra Indígena (TI Catitu), lá vivem famílias ribeirinhas, extrativistas e indígenas que migraram de áreas afastadas da região do Médio rio Purus.

Neste contexto, a aposentadoria dos moradores mais velhos, pais e avós constitui-se a renda fixa para muitas famílias neste universo. É importante também mencionar que os programas do governo federal, como bolsa família, hoje configuram uma ajuda na renda familiar. Os empregos formais estão quase sempre ligados ao funcionalismo público, Prefeitura, como por exemplo professores e agentes de saúde. Alguns poucos desses sujeitos são absorvidos pelo comércio local e, ou pelos serviços domésticos. Alguns indígenas vendem artesanatos para aumentar a renda (mas esta atividade é mais limitada, primeiro porque a população local não se interessa por este tipo de produto, e segundo porque os sujeitos precisam adquirir a matéria prima nas aldeias). A atividade agrícola é praticada, sobretudo, pelos mais velhos, pais e avós que circulam entre as aldeias e a cidade. Os mais jovens vão à roça apenas quando não estão estudando. 
Ressaltamos que este bairro tornou-se de extrema importância, enquanto espaço social e lócus dessa pesquisa. O mesmo é concebido como o bairro mais indígena da cidade. Nesse bairro conversarmos e entrevistamos pais, jovens estudantes indígenas e não indígenas e professores. Entramos em suas casas e percebermos um pouco de suas vidas, o lugar de suas intimidades, expectativas e sonhos. Assim identificamos a existência de um processo de estigmatização vivido pelos jovens que chegaram para estudar, e adultos que nasceram e/ou residem no mesmo.

Pensamos o bairro da Fonte enquanto espaço social, constituído a partir das relações que estão permeadas de distinções (BOURDIEU, 1998). Desta forma, na fala de alguns desses sujeitos é possível notar que os não indígenas já os olham com uma carga de preconceito:

\begin{abstract}
“- Até o ano passado, eu estudei na Escola Francisca Mendes no Bairro da Fonte. Agora estou fazendo primeiro ano do ensino médio na Escola GM, no primeiro dia de aula, durante apresentação dos alunos novatos, o professor perguntou onde tínhamos estudado quando mencionei que tinha estudado no Bairro da Fonte na Escola Francisca Mendes todos ficaram zombando inclusive o professor que ficou rindo." (Indígena Paumari) **Ela é a única indígena nesta turma.

"Tem muito preconceito com o bairro da Fonte. Quando ainda estávamos nos formando nossos amigos e colegas da universidade que moravam em outros bairros ou próximos do Centro, nas ruas próximas da praça sempre diziam que: '- Lá no bairro da Fonte só moram índios e caboclo...casa no bairro da Fonte nem dada eu quero. E sempre se alguém do Bairro morria, eles sempre perguntavam quem matou.' E, eles sabiam que nós morávamos lá." (Professora não indígena que leciona na Escola Francisca Gomes de Mendes e mora no bairro da Fonte )
\end{abstract}

Nesse sentindo, a posição que esses agentes sociais assumem efetiva-se na criação da distinção entre eles e os outros, pertencentes a outros bairros e que assumem e concebem uma ideia de centro. Muitos dos sujeitos que ali residem, estudam na Escola Municipal Francisca Gomes de Mendes. Escola com uma presença indígena significativa. Nela ocorrem as aulas do Projeto 'Eu Sou bilíngue' onde indígenas das etnias Apurinã e Paumari podem estudar suas línguas na cidade. Por outro, lado nesse espaço ocorre uma relação de constante tensão entre pais, professores, alunos indígenas e não indígenas.

Os pais mencionam que os professores têm preconceitos com seus filhos porque são indígenas. Os alunos indígenas, por outro lado, mencionam que não têm problemas com os professores, mas com os colegas não indígenas que os xingam e por preconceito evitam realizar tarefas juntos. Os professores falam que apesar de alguns alunos 
indígenas comportarem-se de forma bastante tímida e terem dificuldades de acompanhar as aulas, eles não são problema. O problema são os pais que não aparecem na escola. (ver falas abaixo):

"Este sofreu muito porque ele não gostava que os outros, os outros alunos diziam assim: “- A ele é índio Paumari...”. Ele arrumava briga na escola. Aí eu era chamada, quando não era eu, era o pai dele que ia lá, e já tava feita a confusão. Eles falavam assim: "O caboclinho eles chamavam, esse caboclinho aí...' E meu filho nào gostava que chamassem ele de caboclinho, né!!. Aí sempre eu avisava: “-Meu filho é assim mesmo, aqui na cidade...a gente pega estas coisas,mas só que não dá para tá aí todo tempo brigando com os outros alunos. Mas para ele se não fizesse isso não estava bem para ele. E sempre doía na gente, né vê o filho da gente né e a gente como índio Paumari levava na cara sempre...Uma vez aqui nessa escola aqui, onde ele estudava uma vez eu fui chamada, aí ela disse: "A porque seu filho, ele zombou da deficiência de um menino.” Aí eu falei assim: '-Mas ele nào fez isso!'. Aí meu filho disse: '- Não mamãe não foi porque eu zombei da deficiência dele até porque eu tenho um irmão deficiente também, então isso não passou pela minha cabeça. Só que ele me chamou de Caboclinho sem vergonha por isso eu achei ruim...". A diretora disse "Nào pode acontecer isso". Aí eu disse, pois é diretora a senhora está aqui para tomar providência disso. Nós, eu e o pai dele que trabalha lá para os parentes dele, não temos como vigiar a escola. Quando o pai dele não tinha este emprego, o pai dele sempre fazia surpresas e vinha na escola, mas agora não tem mais condição. Eu sei que isso não é bom, em casa nós sempre falamos com nossos filhos. Todo mundo sabe que nós somos índios e sempre nós somos discriminados, mas dizemos que ele não deve fazer isso, brigar na escola. Aí a diretora disse: “-É mais ele tem parentagem com Apurinã, não é?”Aí eu respondi: 'O pai dele, o pai do meu menino é filho de apurinã mesmo, verdadeiro..."Aí ela disse: “- E, ele é filho de Apurinã?”Aí eu disse: '- Claro que é'. Pois é não pode acontecer isso, disse a diretora." (Mãe de um aluno indígena)

"Os problemas dos alunos indígenas é que eles faltam bastante e os pais não vêm explicar. Mas visitando as suas casas descobrimos que no inverno eles viajam para as aldeias. Lá também percebemos que os pais são simples, mas recebem a gente bem. E dizem que não ensinam para os filhos porque eles não sabem.. Em relação ao preconceito dentro da sala de aula, eu tento trabalhar bastante isso por isso acho que a relação com os colegas não indígenas é normal" (Professora da Escola Francisca Gomes de Mendes)

E, finalmente, os colegas de classes não indígenas afirmam que não consideram ruim ou problema a presença de alunos indígenas na escola. Mas através de entrevistas, obtivemos alguns depoimentos que mencionavam que não entendiam o que esses indígenas vinham fazer na escola da cidade, eles tinham que permanecer em suas aldeias. A dificuldade de permanecer na cidade e na escola foi recorrentemente mencionada por inúmeros indígenas Paumari e Apurinã. (BRUNO, 2015)

\section{Ideologias Linguísticas: Uma Primeira Discussão}

Ao utilizar a abordagem da Ideologia Linguística é preciso atentar e definir o 
que estamos chamando de "Ideologia". De acordo com Woolard (1998, p. 5-7), os linguístas antropólogos descrevem e utilizam essa noção a partir de quatro perspectivas: a) Ideologia como um conjunto de ideias e conceitos referentes a fenômenos mentais. Representações subjetivas, crenças e ideias muitas vezes conscientes; b) Ideologia como algo derivado ou em resposta de uma experiência ou interesse particular de uma posição social; c) Ideias, discursos ou práticas de significação em serviço de adquirir ou manter poder; d) E uma quarta perspectiva, onde ideologia numa visão marxista está relacionada à distorção, ilusão, mistificação. Em geral, excluindo a concepção marxista, as três perspectivas são recorrentemente observadas e utilizadas nos estudos sobre ideologias linguísticas.

Dessa forma, nesta primeira análise, fundamento esta discussão nas ideias de Kroskrity (2000a). Para ele, a noção de ideologia linguística baseia-se em quatro ideias fundamentais: (1) As ideologias linguísticas representam uma percepção sobre a língua e o discurso que é construída conforme os interesses de um grupo sociocultural específico; (2) As ideologias linguísticas são múltiplas, uma vez que são múltiplas as divisões sociais significativas e as perspectivas associadas a cada grupo, ou sujeito social; (3) Os membros de uma determinada sociedade/comunidade detêm diferentes graus de consciência sobre as ideologias locais de e sobre as suas línguas. E finalmente, as ideologias linguísticas são mediadoras entre as estruturas sociais e os tipos de fala (KROSKRITY, 2000b, p. 8-21)

Estudar e compreender as ideologias linguísticas dos sujeitos sociais permite-nos observar a relação entre representações sociais e a representações da fala. Neste sentido, é possível averiguar as relações entre língua e identidade, língua e questões estéticas e morais, como também noções de pessoas e de grupo desses sujeitos. Para Silverstein (1979), ideologias linguísticas são um conjunto de crenças sobre as línguas articuladas pelos seus usuários que muitas vezes justificam, percebem e explicam a estrutura e como usam suas línguas (é importante ressaltar que a estrutura linguística e a ideologia linguística não são inteiramente independentes, mas nem tão pouco uma determina a outra). Assim, é possível notar que em alguns contextos, os sujeitos sociais (falantes) não apenas avaliam, mas também apropriam-se de alguns recursos linguísticos (empréstimos, ou certas estruturas linguísticas) dos grupos com quem eles estão em contato revelando-se assim múltiplas ideologias linguísticas. (GAL, 1987; HILL,1998). 
Muitas das pesquisas relacionadas com a abordagem da Ideologia Linguística busca compreender quais as crenças, representações e atitudes, os grupos sociais têm sobre suas línguas. De acordo com Phillips (2000) é importante agregar a noção de MULTISITUADA para os estudos de Ideologias Linguísticas tendo em vista que as mesmas podem ser vinculadas a contextos e processos complexos que se sobrepoem (ex: classe, gênero, clã, geração, formação escolar, entre outros aspectos). Neste artigo, compartilhamos da perpectiva de que:

"Ideias vivem e são representadas através de discurso. Elas têm casas e lugares, elas estão baseadas em práticas... ideias não estão flutuando no ar, ou estão apenas nas cabeças dos indivíduos, mas elas são configuradas nas organizações sociais através da interação face a face;" (PHILLIPS, 2000, p. 29)

Assim, nestes processos onde observamos "ideologias linguísticas" sendo requisitadas ou acionadas é importante atentar para o papel dos agentes, o lugar que ocupam e a rede de relações em que estão implicados para observar processos de apagamentos, produções de homogeneidades e criações de diferenças. Além da noção do que é verdade, "moralmente" bom e esteticamente agradável sobre uma lingua.

"Eu falo assim né...quando eu falo com eles na língua, eles falam assim: “-Mamãe, o que é isso? Aí eu falo para eles. Para mim eu acho que na cidade é importante aprender Paumari e Português, não é? Porque como eu falei para minha filha, hoje eu pelo menos sei falar assim né, só que eu não sei colocar muito bem no papel é por isso que eu estava dizendo... meus filhos é muito bom e importante aprender nosso idioma porque isso é nossa cultura e vocês vão aprendendo porque quando vocês tiver a família de vocês, vocês vão ensinando as crianças de vocês." (Indígena Paumari);

"Meus filhos falam que nossa língua é diferente, é pesada.... Eles acham o Paumari um língua feia, mas eu digo para eles que é bom falar outras línguas para os brancos não entenderem, mas eles dizem que Paumari é feio justamente porque os brancos não entendem. Dentro de casa, a gente fala tudo entremeado Paumari e Português por isso eu falo que é misturado igual carne com banha... Meus filhos começam a mangar de mim quando eu falo com eles em Paumari." (Indígena Paumari);

Quando consideramos que a fala é uma das maneiras de se distinguir entre classes de pessoas em termos de status e prestígio, não podemos desconsiderar também que diferentes códigos em contato são avaliados diferentemente, de acordo com dimensões como beleza e lógica. A habilidade de se falar efetiva e belamente uma língua é uma maneira de se distinguir entre os outros. Desta forma, o estilo de falar do indivíduo ou de um grupo social em alguns contextos são tratados como "um desvio" em relação às normas linguísticas (BOURDIEU, 2008) sendo o falante censurado, estereotipado e recorrentemente objeto de uma violência simbólica. 
"Eles têm sim, eles têm medo que os outros fiquem zombando deles, mas eu falo para meus filhos assim: "-o jeito do índio é assim... quem sabe o idioma da gente é muito mais importante do que só saber Português porque aí quando você não quer dizer nada assim na frente do outro, dái a gente só fala na língua...eu acho tão engraça- do Jarawara na praça quando eles conversam assim quando eles querem dizer alguma coisa, eles falarem na língua deles mesmos. E isso é que eu digo para minhas filhas que é importante. A mais pequena, a menor não tem vergonha, mas as minhas filhas mais velhas (adolescentes), elas têm vergornha" (Indígena Paumari).

"Nós falamos Paumari misturado com Português, Paumari eu acho mais bonita, mas é importante também aprender Português, Espanhol e Inglês também acho estas línguas bonitas." (Jovem Paumari)

"Dentro de casa eu falo com eles mais Paumari, e eles entendem. E eles respondem em Paumari também. Eu acho bonita, os dois, minha língua e Português... Eu falo Português pouquinho com minha filha, mas eu acho melhor falar minha língua." (Indígena Paumari);

Atitudes em relação as línguas, conceitos sobre 'si' e os 'outros' e os significados atribuídos e as performances da fala são importantes guias que podem contribuir na compreensão e nas situações e contextos de línguas em contato. A língua pode ser vista como um locus privilegiado do processo político. As ideologias linguísticas são múltiplas, uma vez que são múltiplas as redes sociais a que estão vinculados estes agentes e as perspectivas associadas a cada grupo (KROSKRITY, 2000b). Nestes processos conflituosos, nós somos desafiados a compreender também os processos empregados por grupos específicos que têm suas ideologias linguísticas silenciadas. E esse silenciamento é naturalizado pelos seus próprios agentes sociais que acreditam que suas línguas não têm valor, são inferiores ou menos bonitas:

“...eles se sentem inferior porque falam língua indígena...todas as línguas são bonitas, mas com o Português a gente se acha mais bonito, mais superior...” (Indígena Paumari)

“Os Apurinã da geração de 45 anos para baixo não falam a língua e alguns sentem vergonha, outros justificam o fato de não falar devido a própria trajetória da família que sofreram bastante preconceito, ou segundo alguns falam já está bastante misturado...”. (Indígena Apurinã);

“...muitos pais não querem que os filhos aprendam ou sejam alfabetizados em Paumari, pois eles acham que Paumari os filhos aprendem em casa, Paumari não é uma língua bonita e que na escola mesmo da aldeia tem que aprender é bem Português. Pois atrapalha muito esse negócio de ensinar aos filhos deles duas línguas. Nós professores, nós defendemos dizendo: "Vocês sabem falar, mas não saber ler e escrever em Paumari..." É estranho por que tem gente que vê a gente falando na língua e ficam magando de nós. (Indígena Paumari) 
Observemos que, na fala acima, o domínio da língua portuguesa é altamente valorizado, também é seu aprendizado recorrentemente mencionado como uma das principais motivações na escolha de alguns pais de mandarem os filhos para estudar na cidade, ou se mudarem com toda família.

\footnotetext{
"Hoje o pessoal da cidade vê os indígenas diferente, mas antigamente, os índios não ficavam na praça, eles tinham até vergonha de mostrar sua cultura, eles não falavam na língua né...porque teve gente que falou para mim que descobriu que seu esposo falava língua indígena quando viu um parente indígena chegar de Pauini- um Apurinã e viu esta pessoa falando na língua com seu marido, e ela não sabia. Para ver o tanto, o quanto ele tinha vergonha de dizer que era indígena. E na aparência dele, ele não nega...” (Indígena Apurinã)
}

As situações descritas acima demonstram os dilemas, as representações e ideologias de dois campos: os das línguas indígenas (neste caso Paumari e Apurinã) e o da língua portuguesa:

\begin{tabular}{|c|c|}
\hline $\begin{array}{c}\text { LÍNGUAS INDÍGENAS } \\
\text { (Paumari e Apurinã) }\end{array}$ & LÍNGUA PORTUGUESA \\
\hline ORALIDADE & ESCRITA \\
\hline FAMÍLIA & $\begin{array}{c}\text { ESTADO (Espaço escolar, } \\
\text { Bancos,Secretarias) }\end{array}$ \\
\hline INFORMAL & FORMAL \\
\hline TRADIÇÃO & MODERNIDADE \\
\hline
\end{tabular}

No entanto, é preciso atentar que não podemos delimitar esses dois universos acima expostos de forma tão rígida no quadro, pois a própria ideia de oposição entre as línguas indígenas e o português vê-se confrontada por uma relação de continuidade. No caso dos Apurinã, muitos denotam vergonha por não falar Apurinã em nenhum dos espaços (doméstico ou público) e gostariam de aprendê-lo. Por outro lado, no caso dos Paumari essa delimitação também não é tão fechada. Nos depoimentos observamos que recorrentemente, os pais mencionam que utilizam e falam dentro de casa, as duas línguas (Paumari e Português) com os filhos. Nos espaços públicos também observamos o uso das duas línguas. E nos quatro últimos anos, numa escola localizada no Bairro da Fonte, existe um movimento de ensino das duas línguas por parte dos próprios agentes sociais indígenas através do "Projeto Eu Sou Bilíngue". Nesse sentido, é importante 
atentarmos que se o Português atua tanto no domínio doméstico quanto nos 'espaços buracráticos/oficiais', as línguas indígenas também estão encontrando seus espaços:

\footnotetext{
"Agora a gente tem voz, podemos conversar com a FUNAI e outras organizações porque também eles vêem que a gente está incentivando nossos próprios parentes, pois o MEIL $^{2}$ quer incentivar o uso da nossa língua e cerimônias na cidade..." (Indígena Paumari)

“...quando a gente descobre parentes com 50 anos dizendo: '-Eu sei falar na língua' como hoje tem um rapaz que está dando aula na língua Apurinã, então pra gente é um orgulho. $\mathrm{O}$ que passou para traz teve momentos ruins, mas a língua é uma prioridade se você mora na cidade e fala a língua é muito mais melhor pra gente, eu penso desse modo.” (Indígena Apurinã)

“A língua que está mais perdida é a língua Apurinã por isso eu acho este projeto - Eu Sou Bilíngue super importante para os Apurinã na cidade falar sem vergonha..." (Indígena Apurinã)
}

\section{CONCLUSÃO}

As representações e os usos da língua portuguesa e das línguas indígenas na cidade de Lábrea variam internamente em cada grupo, de acordo com suas experiências particulares e as ideologias que aderiram. Algumas famílias internalizaram as representações estigmatizadas da população regional não indígena a respeito de suas línguas e culturas. Por outro lado, também é importante ressaltar que as línguas indígenas estão tornado-se para os agentes socais e comunidades indígenas nas cidades um dispositivo e instrumento não só para as lutas pelo reconhecimento étnico, como também politicamente demarcando um espaço social.

Nas cidades, os indígenas constroem um mundo de símbolos e estabelecem uma série de redes sociais através das associações e organizações indígenas e dos encontros e desencontros com diversas instituições do Estado (ALMEIDA; SANTOS, 2008). Por outro lado, vivem também como agentes sociais estigmatizados, pois os critérios culturais são usados para marcar desigualdades e atitudes de escolha, neste sentido eles estão constantemente num processo de tensão e conflito com seus corpus e habitus. Durante a pesquisa de campo, observamos como algumas indígenas circulavam na cidade, ao passar numa loja notamos agentes sociais indígenas amamentando seus filhos

\footnotetext{
${ }^{2}$ MEIL - Movimento dos Estudantes Indígenas de Lábrea
} 
como tivessem em suas aldeias - postura muitas vezes estigmatizada pelos não indígenas. É importante ressaltar também que grande parte destes indígenas trabalham na chamada economia informal ou em atividades temporárias: venda de artesanato, farinha e banana, biscates e em casas de família. Vivendo nas cidades, muitos destes indígenas frequentam escolas que desconhecem suas histórias e experiências. (BRUNO; MENEZES, 2012)

Assim seus corpos e suas línguas são estigmatizados até ajustarem-se a novas formas de se portar e falar, como um ritual de passagem em que o indíviduo deve atravessar a fim de mudar seu status ou sua posição social (GENNEP, 1960) - posturas corporais e variantes linguísticas que lhes são impostas. No entanto, para isso é necessário que o corpo e a língua sejam "aprimorados", pois os estigmas que eles carregam são múltiplos e permeados por questões de autoridade, resistência, identidade e distância social onde, através das línguas e seus usos podemos ver estratégias de inclusão e/ou exclusão; oportunidades e discriminação postas em ação onde as pessoas constroem suas vidas e suas palavras sob condições de constrangimentos.

\section{REFERÊNCIAS}

AGHA, Asif. Language and Social Relations. Cambridge: Cambridge University Press, 2007.

ALMEIDA, A.W. B.; SANTOS, G. S. do (org.). Estigmatização e Território: Mapeamento situacional dos indígenas em Manaus. Manaus: Projeto Nova Cartografia Social da Amazônia / Editora da Universidade Federal do Amazonas, 2008.

BONILLA, Oiara. O Bom Patrão e o Inimigo Voraz: Predação e Comércio na Cosmologia Paumari. Mana, 11 (1), 2005, p. 41-66.

. Des proies si désirables. Soumission et prédation pour les Paumari d'Amazonie brésilience. Tese (Doutorado), Ecole des hautes études en scienses sociales, Paris, 2007.

BOURDIEU, Pierre. O Poder Simbólico. Rio de Janeiro: Bertrand Brasil. 2004.

. A Economia das Trocas Linguísticas: O que falar quer dizer. São Paulo: Editora da USP, 2008.

BRANDÃO, Ana Paula B. Dicionário da Língua Apurinã. Trabalho de Conclusão de 
Curso (Licenciatura em Língua Portuguesa). Faculdade de Letras, Universidade Federal do Pará, Belém, 2006.

BRUNO, Ana Carla. Relatório Final Técnico-Científico do Projeto "LÍNGUA e DESIGUALDADE SOCIAL: Processos de politização e territorialização das línguas Apurinã e Paumari no município de Lábrea. Manaus (Projeto Edital Universal/FAPEAM). 2015.

BRUNO, Ana Carla; MENEZES, Thereza C.C. A floresta e sociedade: tradição e cultura. In: HIGUCHI, M.I.G.; HIGUCHI, N. (eds.). A floresta e suas múltiplas dimensões: uma proposta de educação ambiental. 2a . Ed. Rev. e Amp. Manaus: INPA/CNPq, 2012.

CHAPMAN, Shirley; SALZER, Meinke. Dicionário bilíngue nas línguas paumari e portuguesa e perfil gramatical. Porto Velho: Sociedade Internacional de Linguística, 1998.

COLLINS, James. Our Ideology and Theirs. In Language Ideologies: Practice and Theory. In: SCHIEFFELIN, Bambi B.; WOOLARD, Kathryn A.; KROSKRITY, Paul V. (ed.). New York: Oxford University Press, 1998, p. 256-269.

DAS, Veena. Critical Events: An Anthropological Perspective on Contemporary India. Oxford: Oxford University Press, 1995.

Fronteiras, violência e o trabalho do tempo: alguns temas wittgensteinianos. Rev.

Bras. Ci. Soc., São Paulo, v. 14, n. 40, June. 1999. Disponível em http://www.scielo.br Life and Words: violence and the descent into the ordinary. Berkeley: University of California Press, 2007.

FACUNDES, Sidney da Silva. The Language of the Apurinã People of Brazil. Tese (Doutorado), University of New York at Buffalo, 2000.

Historical linguistics and its contribution to improving the knowledge of Arawak. In: HILL, Jonathan D.; SANTOS-GRANERO, Fernando. (eds.), Comparative Arawakan histories: rethinking language family. Urbana and Chicago: University of Illinois Press, 2002.

GAL, Susan. Codeswitching and Consciousness in the European Periphery. American Ethnologist 14, 1987, p. 637-653.

Multiplicity and Contention among Language Ideologies: A Commentary. IN: SCHIEFFELIN Bambi B.; WOOLARD, Kathryn A.; KROSKRITY, Paul V. (Eds.), Language Ideologies: Practice and Theory. New York: Oxford University, 1998. 
GENNEP, A. Van. The rites of passage. London: Routlegde \& Kegan Paul, 1960.

IRVINE, Judith; GAL, Susan. Language Ideology and Linguistic Differentiation. IN: KROSKRITY, Paul V. (Ed.), Regimes of Languages: Ideologies, Politics, and Identities. New Mexico: School of American Research Press, 2000.

HANKS, William F. Língua como Prática Social: das relações entre língua, cultura e sociedade a partir de Bourdieu e Bakhtin. São Paulo: Cortez, 2008.

HILL, Jane. Today Theres is no Respect: Nostalgia, "Respect", and Oppositional Discourses in Mexicano (Nahuatl) Language Ideology. IN: SCHIEFFELIN Bambi B.; WOOLARD, Kathryn A.; KROSKRITY, Paul V. (Eds.), Language Ideologies: Practice and Theory. New York: Oxford University, 1998.

http://www.funai.gov.br/index.php/indios-no-brasil/o-brasil-indigena-ibge. Acesso em 26 março. 2018.

KROSKRITY, Paul V. Regimes of Languages: Ideologies, Politics, and Identities. New Mexico: School of American Research Press, 2000a.

Regimenting Languages: Language Ideological Perspectives. In: KROSKRITY, P. V. (org.), Regimes of Language: Ideologies, Polities, and Identities. Santa Fe: School of American Research Press, 2000b, p. 1-34.

LIMA, Bruna Fernanda Soares de. Variação, Mudança e o 'Duplo Vocabulário' na Língua Apurinã (Aruak). Trabalho de Conclusão de Curso - Faculade de Letras, Universidade Federal do Pará. Belém: UFPA. 2013

MARCUS, George E. Ethnography in/of the world system: the emergence of MultiSited Ethnograpy. Annual Rev. Antropol 24, 1995, p. 95-117.

MENEZES, Thereza; BRUNO, Ana Carla. Territórios indígenas na escola: língua e mobilização social no Amazonas. Revista SURES, UNILA, 2014.

NASCIMENTO COSTA, Patricia do. Pupỹkarypikarawa athe. (Nós somos índios.) Língua e Identidade Apurinã (Aruák): estudos baseados em relatos contemporâneos. Dissertação (Mestrado em Estudos Linguísticos), Programa de Pós-Graduação em Letras, UFPA, Belém, 2016.

PEIRANO, Mariza. A Favor da Etnografia. Rio de Janeiro: Relumé- Dumará, 1995.

PHILIPS, Susan U. Language and Social Inequality. IN: DURANTI, Alessandro (Ed.), A Companion to Linguistic Anthropology. Oxford: Blackwell Publishing, 2006.

SANTOS, Gilton Mendes dos. Álbum Purus. Manaus: EDUA, 2004. 
SCHIEL, Juliana. Entre Patrões e Civilizadores: Os Apurinã e a política indigenista no meio rio Purus na primeira metade do século XX. Dissertação (Mestrado em Antropologia Social), Unicamp, Campinas, 2000.

- Tronco Velho: Histórias Apurinã. Tese (Doutorado em Antropologia Social), Unicamp, Campinas, 2004.

SILVERSTEIN, Michael. Language Structure and linguistic Ideology. IN: CLYNE, Paul R.; HANKS, William F.; HOFBAUER, Carol L (Eds.), The Elements: A Parassession on Linguistic Units and Levels. Chicago: Chicago Linguistic Society, 1979

TAUSSING, Michael. Xamanismo, colonialismo, e o homem selvagem. São Paulo. Paz e Terra, 1993.

VIRTANEN, Pirjo Kristiina. 2015. Fatal Substances: Apurinã's Dangers, Movement, and Kinship. Indiana 32, p. 85-103, 2015.

WOOLARD, Kathryn. Introduction: Languge Ideology as a Field of Inquiry. IN: SCHIEFFELIN, Bambi B.; WOOLARD, Kathryn A.; KROSKRITY, Paul V. (eds.), Language Ideologies: Practice and Theory. New York: Oxford University, 1998. 